\title{
The Training Management of Designing Life Skill and Chemo- Entrepreneurship Based Learning to Chemistry Teachers of Senior High School in Semarang
}

\author{
Sri Susilogati Sumarti ${ }^{1}$, Haryono ${ }^{2}$ \\ ${ }^{1}$ (Department of Chemistry, Semarang State University, Indonesia) \\ ${ }^{2}$ (Department of Psychology, Semarang State University, Indonesia)
}

\begin{abstract}
The improvement of teachers' professionalism in life skill and CEP based chemistry learning is needed. This research aims to find the model of training management in designing life skill and CEP based chemistry learning with details of (1) describing the design, (2) obtaining the test result, (3) finding the effectiveness, and (4) finding the description of the training model in designing life skill and CEP based chemistry learning. This research used Research and Development $(R \& D)$ approach with stages of $(1)$ conducting a preliminary study, (2) determining the empirical model based on the analysis result of preliminary study, (3) developing the empirical toward the hypothetical model, (4) testing the effectiveness of the hypothetic model through limited field test, and (5) improving the hypothetical toward the finding model. The data gathering was held by observation, interview, questionnaire, and documentation. The data analysis was held by qualitative and analytical descriptive using paired t-test with level of significance of 0.05. Preliminary study showed that the teachers needed the training in life skill and CEP based chemistry learning to increase their competence in designing, implementing, and evaluating life skill and CEP based chemistry learning. The findings showed that the training model in designing in life skill and CEP based chemistry learning was effective to improve the quality of teachers in implementing chemistry learning. It is recommended for training providers that the training model in designing in life skill and CEP based chemistry learning is excellent to be developed within a wider scale.
\end{abstract}

Keywords: chemo-entrepreneurship, life skill, model of training management

\section{INTRODUCTION}

Development of entrepreneurship among educators is crucial because educators are agents of change who are expected to instill characteristics, nature and character, as well as the entrepreneurial spirit for learners. Entrepreneurial-minded education is an education which applies the principles and methodology to the formation of life skills to the learners through a curriculum developed at school. ${ }^{[1]}$

Various attempts have been made to improve the quality of teachers in order to not only accelerate the learning process of students in achieving cognitive but also affective and psychomotor aspects. ${ }^{[2]}$ One of them is by developing a life skill and chemoentrepreneurship (CEP) based chemistry learning. The learning process is done by integrating aspects of life skills and entrepreneurship in learning activities. ${ }^{[3]}$

The author observed 40 teachers of chemistry Lesson Teachers' Council about the experience of training and carrying out a life skill and CEP based chemistry learning. The result showed that (1) in general, all teachers were experienced in competency enhancement training; $80 \%$ of teachers experienced in chemistry learning training, and $90 \%$ of teachers have not attended training related to life skill and CEP chemistry based learning, (2) a 95\% of chemistry teachers implemented chemistry learning without integrating life skills and CEP because of difficulties associated with entrepreneurial learning design and lack of time and available cost, (3) a 95\% of teachers did not link the concepts of chemistry and the concept of entrepreneurship. The data indicated that the lesson plans created by teachers did not link the concept to the manufacture of chemistry products, (4) a 95\% of teachers have not carried out life skill and CEP based chemistry learning, (5) a 95\% of observed teachers stated that they really needed the competency improvement in applying life skill and CEP based chemistry learning.

The problems in this study were: (1) how the chemistry learning training model and CEP-based life skill is and (2) whether the model training is effective to enhance the ability of teachers in carrying out life skill and CEP based chemistry learning.

\section{METHOD}

Stages covered in this study, followed the model of Borg and Gall (1989:784-785) with some simplification as follows: (1) conducting a preliminary study, (2) setting the empirical model based on the analysis of the preliminary study, (3) drafting the hypothetical model based on empirical model, (4) designing 
validation by experts and practitioners, (5) improving the designed model, (6) performing a design trial, (7) evaluating the improved design to produce the finding model, and (8) writing research reports. ${ }^{[4]}$

Techniques of data collection were interview, observation, and documentation using the instruments in the form of questionnaires, interview guides, observation sheets, and field notes. Analysis of data was performed by using qualitative and quantitative approaches. A qualitative approach is needed to clarify the description of life skill and CEP based chemistry learning model. Descriptive quantitative analysis is needed to measure the variables of the ability of teachers before and after training, participants' responses to the implementation of training, and criteria for the effectiveness of the model based on the variables measured.

\section{RESULTS AND DISCUSSION}

The training model of life skill and CEP based chemistry learning model (Fig 1) is a management model of organizing training programs in order to improve the learning ability of teachers to carry out life skill and CEP based chemistry learning. ${ }^{[5]}$

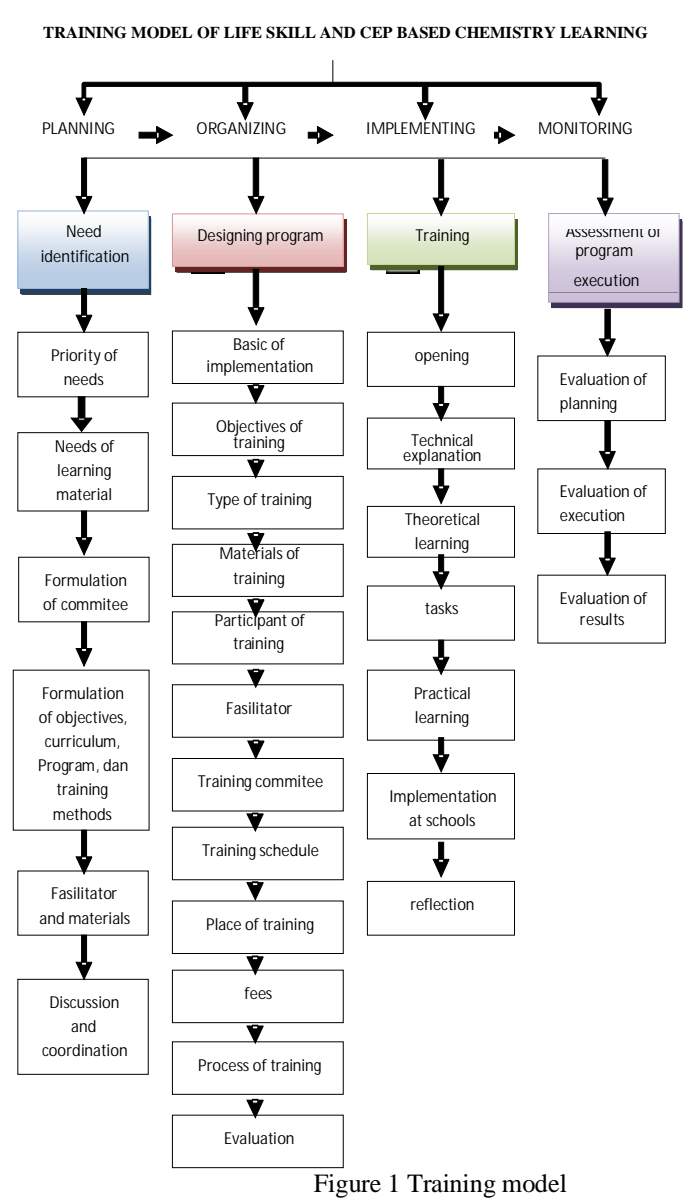

Organizing activities include preparation of design implementation which consists of components: principles of implementation, objectives of implementation, activities, training materials, participants, facilitators, organizers, schedules, venue, cost, and evaluation process. Implementation of the training includes activities including: opening, technical explanations, learning of theories, assignments, teaching practice, the implementation of learning at school, and reflection. Observation activities include assessments of program implementation consisting of evaluation of program planning, program implementation and result evaluation. ${ }^{[6]}$

The effectiveness of the model was determined through testing the model by measuring the participants' ability to design learning before and after the training, participants' response in the training implementation, participants' ability to carry out teaching practice at schools, and students' ability to practice in the production, presentation, and entrepreneurship. The increase in teachers' capability to design learning before and after training is presented in Fig. 2. Measurement of the teachers' ability to design life skill and CEP based chemistry learning was conducted on all participants. This ability focused on six key indicators, namely the ability to formulate learning objectives of life skill and CEP based chemistry learning, set learning activities of life skill and CEP based chemistry learning, summarize the learning materials, develop a guide of product 
production, develop sheet assessment of the product and a presentation assessment sheet. It was generally known that a significant increase on the six teachers' skills in designing life skill and CEP based chemistry learning from sufficient to be very high criteria. Even the indicator of teachers' ability to formulate learning objectives of life skill and CEP based chemistry learning and the ability to set an assessment sheet of products have considerably increased. This showed the promising first step to the success of life skill and CEP based chemistry learning due to the purpose of learning is a crucial runway to achieve the target of learning while the product assessment sheet is an assessment tool to measure the extent of achieved indicators. ${ }^{[7]}$

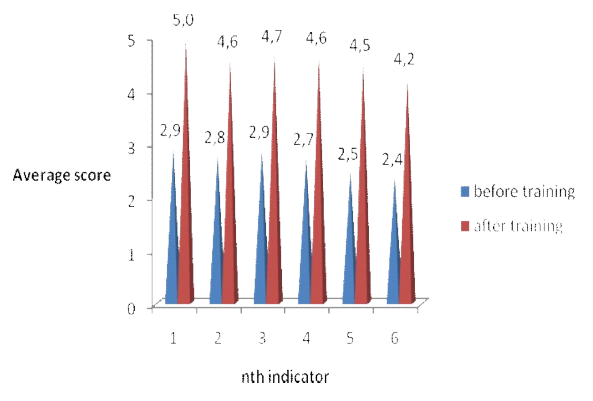

Figure 2. Improvement of teachers' ability to design learning before and after training

Teaching practices at schools, were conducted SMA 16 Semarang, SMA 12 Semarang, MA AlKhoiriyyah, and SMA 1 Semarang with the involvement of two classes for each school; experimental and control group. The control group test were not performed at MA Al-Khoiriyyah because it only has one class. The result of learning practices at schools by teachers in the experimental group and control group are shown in Fig. 3, Fig. 4, Fig. 5, Fig. 6, Fig. 7, Fig. 8, and Fig. 9. Fig. 3 shows that the ability of teachers to design life skill and CEP based chemistry learning for the experimental group and control group had a significant difference. The experimental groups of all schools were able to demonstrate the ability to design life skill and CEP based chemistry learning with very high criteria, whereas the control groups were only in a range of criteria from medium to high except MA Al-Khoiriyah that did not involve a control group in this test because it only has one class with the same teacher. This finding suggested that the training model generated in this study proved effective to train chemistry teachers of senior high schools in improving the ability to design life skill and CEP based chemistry learning. This is due in this training model trained teachers to design life skill and CEP based chemistry learning step by step in a systematic and measured way to achieve the learning objectives which have been set.

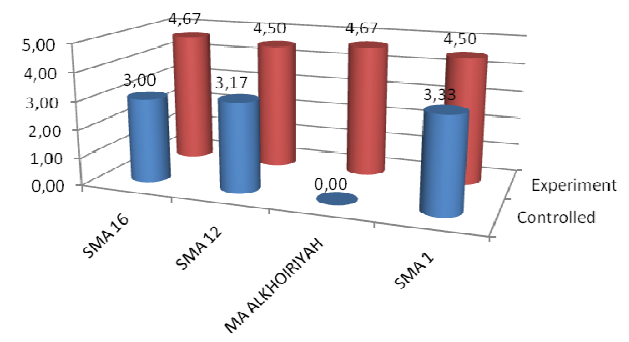

Figure 3. The ability of teachers to design life skill and CEP based chemistry learning

Fig. 4 presents the ability of teachers in carrying out life skill and CEP based chemistry learning including the control groups and experimental groups. Indicators of the ability of teachers to implement learning involves 15 sub-indicators which include the ability to carry out apperception, mention the goals of life skill and CEP based chemistry learning, explain concepts related to life skills and entrepreneurship, determine which products are put into practice, guide students to good manufacturing practices, motivate students' entrepreneurship, guide students to conduct economic analysis of products, the relevance of the lesson plans, interaction with students, product attractiveness, product benefits, product uniqueness, product innovation, the ability to summarize the learning materials, and evaluate the learning. Among the four schools that were designated as samples in this study, MA Al-Khoiriyah was the only school that has only one class for each class that is not possible to pull out the control group as other samples.

It is observed in Fig. 4 that the ability of teachers in carrying out life skill and CEP based chemistry learning for the experimental group was higher than that for the control group with very high criteria for the experimental group and high criteria for the control group. It also is another evidence that the finding model was 
effective to produce chemistry teachers who were able to both design and perform life skill and CEP based chemistry learning. Fig. 3 and Fig. 4 also reveal that probably the initial ability of each teacher at the same school was similar. Because teachers in the control groups did not receive training in how to design and implement correctly and systematic learning, then some sub-indicators in the ability indicators to design and implement learning were unobservable.

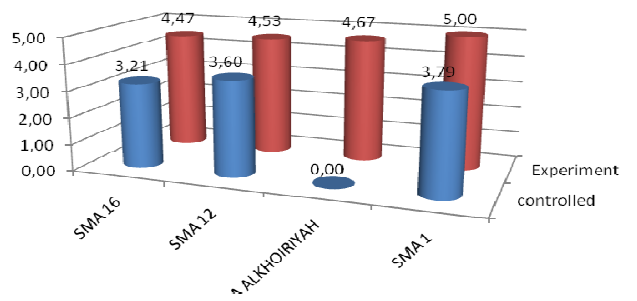

Figure 4. The ability of teachers to perform the life skill and CEP based chemistry learning

Fig. 5 presents the ability of the four school chemistry teachers in evaluating the process and the results of life skill and CEP based chemistry learning for the control group and experimental group, except for MA AlKhoiriyah that only has one class. It can be seen in Fig. 5 that the ability of chemistry teachers in evaluating life skill and CEP based chemistry learning between the control and experimental groups are significantly different from the high criteria for the control group and very high criteria for the experimental group. Thus it can be concluded that the training model of life skill and CEP based chemistry learning was effective to enhance the ability of teachers in designing and carrying out, as well as evaluating life skill and CEP based chemistry learning.

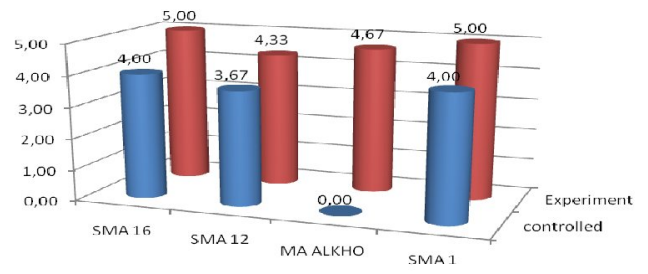

Figure 5. The ability of teachers to evaluate life skill and CEP based chemistry learning

In addition to the ability of teachers in designing, implementing, and evaluating life skill and CEP based chemistry learning as an evaluation of the impact of the training model, an evaluation toward students' activities in life skill and CEP based chemistry learning which has been implemented in four sample schools also has been conducted. This study focused on students' activities including the practice of making chemistrybased life skill products, presentation skills, and entrepreneurship aspects shown in the learning process. By considering that the students from different schools may not have the same initial condition associated with the focus of this research, the three aspects of students' activities observed are discussed for each school without generalization. The results are presented in Fig. 6, Fig. 7, Fig. 8 and Fig. 9.

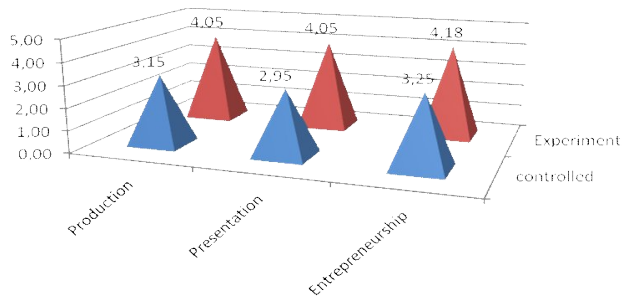

Figure 6. The ability of students of SMA 16 Semarang

Fig. 6 presents the results of the assessment prof production, presentation, and the entrepreneurial spirit of students of SMA 16 Semarang respectively for the control and experimental groups. It can be seen from Fig. 6 that the ability of the experimental group's skills in producing life skill products and presenting the results was higher than the control group. Similarly, an assessment of the entrepreneurial aspects of the experimental group showed a better criteria than those of the control group. The experimental group achieved a very high criteria for 
all three of these aspects while the control group reached the criteria up to medium/adequate. However, in general, the difference is not very significant as the results shown by students of SMA 1 Semarang (Fig. 9) and SMA 12 Semarang (Fig. 7). This is possible because the input of students at each school was relatively the same for all classes. Thus, the training model generated in this study can effectively enhance the ability of teachers in designing, implementing, and evaluating life skill and CEP based chemistry learning. This will have a positive impact on improving students' ability to make a life skill-based chemical products and can directly improve students' entrepreneurial spirit.

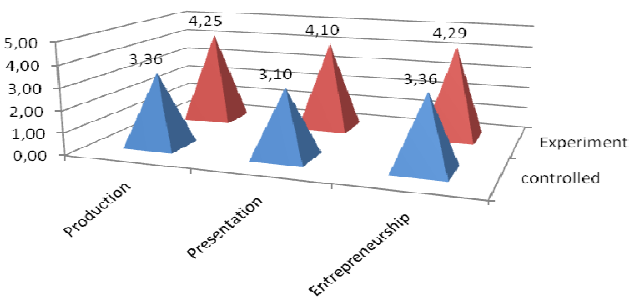

Figure 7. The ability of students of SMA 12 Semarang

The same pattern did not apply to MA Al-Khoiriyah as shown in Fig. 8. Because the school had only one class for each academic year then the data was obtained only from the experimental class. However, by looking at the end result of the class it can be seen that the results of production, presentation, and the students' entrepreneurial spirit of MA Al-Khoiriyah Semarang were relatively similar to the three schools which have a control group, except for the aspects of the entrepreneurial spirit. On this aspect, MA Al-Khoiriyah only showed result in high criteria, while the three other schools already showed results in very high criteria. It could be related to the input of students who tend to be shy and submissive psychologically, so they were less able to think critically and creatively in the capture of existing business opportunities.

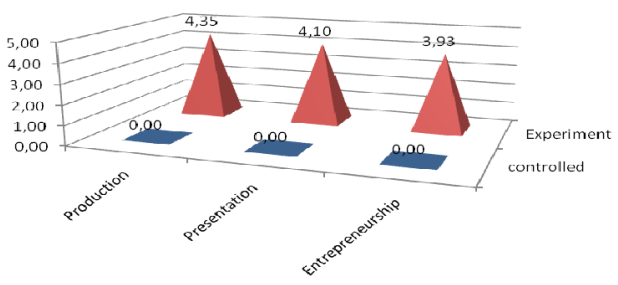

Figure 8. The ability of students of MA Al-Khoiriyyah

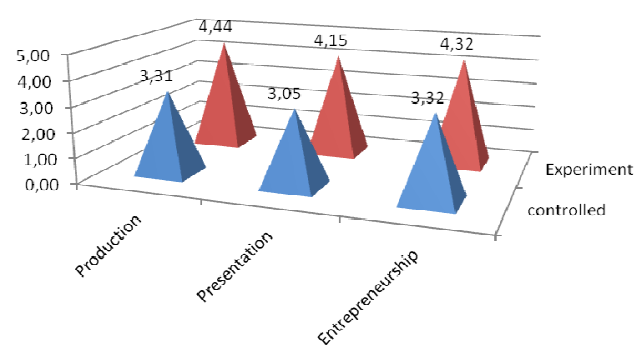

Figure 9. The ability of students of SMA 1 Semarang

The increase in teachers' capability in designing, implementing, and evaluating the learning process was supported by the ability of the excellent coaches and learning strategies. Implementation of learning in the training were as follows: facilitators/trainers as a learning resource facilitating the activities of the learning process with the following steps: (1) delivering the competencies to be achieved, (2) explaining the materials briefly, (3) guiding the drafting life skill and CEP based chemistry learning, (4) training the manufacture of products, and (5) guiding the group discussion. Provision of learning experiences in this training was aimed to increase teachers' ability to both dimensions of the knowledge and skills in designing life skill and CEP based chemistry learning. Chemistry teachers as learning community individually or grouply together with the 
facilitators collaboratively carried out activities in the training process through the steps of: (1) listening carefully the description of materials, (2) conducting practices to plan a life skill and CEP based chemistry learning, (3) manufacturing products with the guidance of instructors, and (4) implementing the designed life skill and CEP based chemistry learning at schools with assistance. The effectiveness of the model was also supported by the responses of participants to the training, which showed good or excellent results. Participants' responses to the implementation of training on life skill and CEP based chemistry learning are shown in Table 1. Effectiveness criteria were determined based on the average score of the indicators broken down into the criteria of less effective, effective, and very effective as shown in Table 2.

Table 1. Evaluation on Training Implementation

\begin{tabular}{|c|c|c|c|}
\hline $\begin{array}{c}\text { Sub } \\
\text { Variable }\end{array}$ & Indicator & Score & Criteria \\
\hline context & $\begin{array}{l}\text { Accordance of training with the } \\
\text { main role of teachers } \\
\text { Accordance of training with the } \\
\text { teachers' expectation } \\
\text { Accordance of training with the } \\
\text { objectives of training } \\
\text { Accordance of training with the } \\
\text { development of curriculum }\end{array}$ & 3.70 & $\begin{array}{c}\text { Very } \\
\text { suitable } \\
\text { Very } \\
\text { suitable } \\
\text { Very } \\
\text { suitable } \\
\text { Suitable }\end{array}$ \\
\hline Input & $\begin{array}{l}\text { Curriculum of training } \\
\text { Preparation of supporting materials } \\
\text { Qualification of trainers } \\
\text { Budget and infrastructure } \\
\text { Schedule } \\
\text { Environment of training }\end{array}$ & $\begin{array}{l}4.23 \\
4.10 \\
4.00 \\
4.10 \\
4.00 \\
3.86\end{array}$ & $\begin{array}{l}\text { Very good } \\
\text { Very good } \\
\text { Good } \\
\text { Very good } \\
\text { Good } \\
\text { Good }\end{array}$ \\
\hline Process & $\begin{array}{l}\text { Methods used by trainers } \\
\text { Interaction between trainers and } \\
\text { trainees } \\
\text { Learning media in training } \\
\text { Available time } \\
\text { Providing opportunities in } \\
\text { questioning }\end{array}$ & $\begin{array}{l}4.40 \\
4.23 \\
4.16 \\
\\
3.80 \\
\end{array}$ & $\begin{array}{c}\text { Very good } \\
\text { Very good } \\
\text { Very good } \\
\text { Very good } \\
\text { Good }\end{array}$ \\
\hline product & $\begin{array}{l}\text { Improving knowledge and } \\
\text { capability } \\
\text { Achieving the objectives of training } \\
\text { satisfyment } \\
\text { Mastery of skills after training } \\
\text { The result of training is in line with } \\
\text { the objectives }\end{array}$ & $\begin{array}{l}4.30 \\
3.93 \\
3.83 \\
3.90\end{array}$ & $\begin{array}{l}\text { Very good } \\
\text { Good } \\
\text { Good } \\
\text { Good } \\
\text { Good }\end{array}$ \\
\hline benefit & $\begin{array}{l}\text { Product benefits to participants } \\
\text { Benefits to students } \\
\text { Benefits to schools } \\
\text { Benefits to development of } \\
\text { competences }\end{array}$ & $\begin{array}{l}4.33 \\
4.16 \\
4.03\end{array}$ & $\begin{array}{c}\text { Very good } \\
\text { Very good } \\
\text { Very good } \\
\text { Good }\end{array}$ \\
\hline impact & $\begin{array}{l}\text { Improvement on teachers' } \\
\text { competencies in life skill and CEP } \\
\text { based chemistry learning } \\
\text { Improvement on teachers' } \\
\text { competencies in motivating students } \\
\text { to be an entrepreneur } \\
\text { Students' motivation to be an } \\
\text { entrepreneur enhanced } \\
\text { Benefits of training to the } \\
\text { development }\end{array}$ & 4.16 & Very good \\
\hline
\end{tabular}

Table 2. The Criteria of Effectiveness of the Finding Model

\begin{tabular}{lcc}
\hline \multicolumn{1}{c}{ Indicator } & $\begin{array}{c}\text { Average } \\
\text { Score }\end{array}$ & Criteria \\
\hline Ability of teachers in designing learning & 4.58 & very effective \\
Ability of teachers in implementing & 4.65 & very effective \\
learning & & very effective \\
Ability of teachers in evaluating learning & 4.75 & very effective \\
Ability of students to produce life skill & 4.27 & very effective \\
products & 4.09 & verfective \\
Ability of students to present the results & 4.18 & very effective \\
Students' entrepreneurial spirit & 4.2 & very effective \\
Process aspect & 3.9 & Effective \\
product aspect & 4.05 & very effective \\
Benefit aspect & 3.9 & Effective \\
Impact aspect & 4.18 & very effective \\
Contextual aspect & 4.05 & very effective \\
Input aspect & 4.53 & very effective \\
Trainer capability & 4.26 & very effective \\
Total average & & \\
\hline
\end{tabular}




\subsection{Conclusion}

\section{CONCLUSION AND RECOMMENDATION}

Based on the results of this study, it can be concluded that: (1) training model of life skill and CEP based chemistry learning was very effective to improve the competence of teachers in carrying out life skill and CEP based chemistry learning, (2) the effectiveness of the training model indicated an increase in the ability of teachers to design life skill and CEP based chemistry learning before and after training and the significant difference in entrepreneurial abilities of students in the control group and experimental group by a teacher who trained and untrained.

\subsection{Recommendation}

The training model of life skill and CEP based chemistry learning should be socialized and made continuous improvements by adjusting to the development of industry and science for teachers to increase their competence in a learning-based entrepreneurship.

\section{REFERENCES}

[1] Basrowi, Kewirausahaan untuk perguruan tinggi (Bogor: Penerbit Galia Indonesia, 2011)

[2] Yateman Aryanto, et al., Strategi pengembangan ilmu kimia indonesia (Yogyakarta: Deputi Bidang Perkembangan, Kementerian Negara Riset dan Teknologi, Diglossia, 2006)

[3] Nusa Putra, Research and development (penelitian dan pengembangan): suatu pengantar (Jakarta: Rajawali Pers, 2011)

[4] W.R. Borg and M.D. Gall, Educational research: an introduction (New York: Longman, 1989)

[5] David R Jeffries, et al, Training for total quality management: practical trainer series (London: Association with the Institute of Training and Development, 1993)

[6] Shipra Vaidya, Developing entrepreneurial life skills: an experiment in indian school, theses, Institute for Small Business \& Entrepreneurship, Glasgow, 2007

[7] Woro Sumarni, Pengembangan model pembelajaran berorientasi chemoentrepreneurship (CEP) terintegrasi ketrampilan generik dengan media chemodutainment (CET) sebagai upaya peningkatan efektivitas pembelajaran kimia dasar, theses, Semarang State University, Semarang, 2007

[8] Jerry W. Gilley \& Steven A. Eggland, Principles of human resource development. (Cambrigde, MA: Perseus Publishing, 2002) 